\title{
STRIKES AND THE PUBLIC: \\ A CONSENSUS?
}

JIM NOLAN*

Strikes are constantly in the news. These, and wage negotiations, provide the public with an image of what industrial relations is all about. While the vast majority of the public are never directly involved as participants in a strike, their "interests" are often invoked in negotiations involving strikes. What is the public reaction to strikes and are strikes a social problem?

Tied to public reaction is the concept of consensus. The stated aim of a democratic society is to arrive at some form of consensus about social actions which may have detrimental effects on some sectors of that society. The overriding determinant in the consensus is the law. Within the industrial field, can some consensus be arrived at concerning the right of unions to back up their demands?

\section{THE PUBLIC REACTION TO STRIKES}

Early work on the public reaction to strikes in the United States is presented by Chamberlain. From analysis of public opinion poll data he concludes :

1) Substantial majorities favour rigorous wartime control of strikes.

2) Substantial majorities favour rigorous control of strikes occurring in peacetime under emergency conditions such as preparation for defence or reconversion from war to civilian production.

3) Majorities would subject all peacetime strikes to restraints, and large minorities would outlaw all peacetime strikes.

4) There is a majority sentiment to prohibit strikes in essential industries or to subject them to restraints.

5) There is a majority sentiment opposed to sympathetic, jurisdictional and general strikes and strikes in the civil service."

While the data he analyses refers to the late 1940s there is no evidence to suggest that United States public reaction has altered substantially since then.

In New Zealand "New Zealand Herald" - NRB polls regularly record public opinion. Recent poll results were :

Question: "What is the single most important problem facing New Zealand?

\footnotetext{
Jim Nolan is a market research worker and an industrial relations student at Victoria University of $V$ eilington

Chamberlain, N.W. (1953) Social Responsibility and Strikes New York, Harper and Bros. pp 65-66
} 
Inflation

The economy in general

Unemployment

Social climate/public morality

Energy crisis/petrol shortage

Industrial relations

Government

Overseas trade

Law and order

Racial harmony

\begin{tabular}{cccc} 
MAY NOV & \multicolumn{2}{c}{ JULY MAY } \\
80 & 79 & 79 & 79 \\
$\%$ & $\%$ & $\%$ & $\%$ \\
25 & 13 & 9 & 11 \\
22 & 22 & 26 & 32 \\
11 & 13 & 10 & 10 \\
9 & 10 & 10 & 10 \\
6 & 11 & 13 & 4 \\
5 & 5 & 7 & 4 \\
4 & 6 & 6 & 7 \\
3 & 6 & 5 & 8 \\
2 & 3 & 2 & 1 \\
1 & - & - & -
\end{tabular}

"Industrial Relations" covers a wide variety of responses, but within the context of the question it is likely to contain a high proportion of negative responses to strikes and unrest.

Chamberlain interprets public reaction to strikes in terms of their "real effect" on the public. ${ }^{2} \mathrm{He}$ also introduces the concept of a "cumulative annoyance factor" - the greater reaction to a strike if it is one of a number occuring at the same time, and a "sympathy factor" - concern for others harshly affected by a strike from those not directly affected themselves. ${ }^{3}$ Bok and Dunlop also identify "harm to the innocent bystander" as one of their five bases for public concern about strikes. ${ }^{4}$ The other four are : internal rivalries within unions, disregard of authority, the high incidence of strikes in America, and a demand for more of labour-management institutions - in the sense that the problem should have been solved earlier.

Public reaction to strikes is centred more on strikes as a cause than on their effect. Inter-island ferry services cancelled by strike action are widely opposed. But inter-island ferry services cancelled because of lack of freight are tolerated. Airports closed by weather are tolerated; airports closed by strikes are not. Roads closed by road works for long periods are tolerated; roads closed by picket lines for short periods are not. Factories closed forever are accepted as sound business sense, progress, and economic rationalisation; factories closed for a day by strikes are the work of economic wreckers. Quite obviously then, public opposition to strikes is more related to the method than the effect. This is tied to the concept that strikes are unnecessary or preventable.

Public reaction however is more than the reaction of those directly affected by a strike. Public reaction (to any matter) is a mixture of the direct effect on the individual concerned, and the individual's assessment of the effect on others and the society at large. It consists of the person balancing up the effect on themselves personally with the effect they observe on other people, and then making a judgement for or against. The effect they observe on other people and on society at large is more often than not received via some form of media - radio, television, newspaper, word of mouth. The reaction then is not a reaction to the effect of an action itself on other people, but a reaction to the 2 Chamberlain, ibid, Chapter 6 and 7.

3 Chamberlain, ibid, p. 111

4 Bok, D.C. and J.T. Dunlop (1970) Labour and the American Community New York, Simon and Shuster.

66 
mediated effect on other people. The reaction then is to the mediated image, not to the effect itself.

The number of people directly affected by a strike is small compared to the number of people who have reaction to it. Since most people's reactions are to a mediated image of the strike, how the strike is presented in the media is of prime importance to the public reaction. The media presentation is the prime determinant of public reaction to a strike.

The Grunwick strike of 1976-78 in Britain is a case in point. The strike actually lasted for two years. Yet most public reaction to the strike was formulated during two weeks in June 1977, when during a period of mass picketing the strike was major news. During the two week period it accounted for nearly a third of all the ITV "News At Ten" broadcasting time available and nearly one seventh of the time available on BBC "Nine O'Clock News". ${ }^{5}$ Even within this period, all commentators agreed that the major focal point of public reaction was the image of a young constable who had been knocked down by a milk bottle. "Wilson (the constable) was left in the road for several minutes, some say a quarter of an hour - with blood streaming from his wound while he was being extensively filmed and photographed". ${ }^{6}$ Public reaction to the strike was formulated basically by this saturation media presentation and by the particular image of the constable.

Public reaction to strikes is obviously not all formulated by mediated information. Some is the result of direct experience. But to ignore the influence of mediated information on public reaction to strikes is to ignore an important part of it.

\section{STRIKES AS A SOCIAL PROBLEM}

The question of strikes as a social problem varies according to the viewpoint taken. From the unitary point of view strikes are a definite social problem. The basis of this view is that there is a state of affairs called "industrial peace" or "normal working conditions". Strikes are a social problem because they upset this industrial peace. It is a view of the world in which there is a state of affairs which is attainable and which all "normal" people would see as desirable. It is the job of industrial relations to bring about this state. To the extent that strikes and industrial conflict occur, the industrial relations system is not working. Some limited debate about the means of bringing about the desired state is allowed, but the desirability of the ends and major operations within the system are regarded as being self evident. Within this framework, strikes are the work of disruptive elements or, in the extreme case, deviant or abnormal behaviour. Strikes are seen as a problem because they upset the normal smooth running of the system. In the extreme case, strikes are seen as not merely disruptive, but as threatening the existence of the system itself. Strikes are a social problem because they upset the system, or worse, because they present a challenge to the system itself.

The pluralist sees strikes not so much as upsetters of tranquility, but as part of the conflict which will inevitably occur but which must be resolved. They are part of the competition of interests between management and labour which management and labour will jointly regulate between themselves, or which in

5 Rogaly, J. (1977) Grunwick London, Penguin. p. 80.

6 Dromey, J. and G. Taylor (1978) Grunwick: The Workers' Story London, Lawrence and Wishart. p. 125. 
the event of a disagreement, may be resolved by the intervention of a third party. Strikes are a social problem not so much in themselves, but in terms of their effect on the people involved - families without an income, production lost, communities divided. The emphasis is not on their elimination, but on their resolution and prevention. Strikes then, according to the pluralist, are a social problem which must be accepted, but which are none-the-less undesirable. They are part of a whole range of social problems which it is unrealistic to expect to disappear, but which are problems for which solutions, at least in the short term, must be found. the public opinion polls mentioned earlier give some indication of the other sorts of similar problems faced by society.

The radical viewpoint, however, is that strikes are not in themselves a social problem. The radical is critical of the defining of strikes as a social problem. In this viewpoint, strikes are defined as a social problem because it suits those who are wealthy and powerful for them to be defined as such. Fox ${ }^{7}$ has stated it thus :

"the selection of some features of the current scene as 'problems' and the denial of the same status to others is determined, not by objective and 'neutral' considerations, but by decisions (which may well be implicitly rather than explicitly formulated) as to what is to be accepted as fixed and unchanging.

The "Golden Rule" - those that have the gold make the rules - has a corollary - those that have the gold also define the problems.

This defining of problems gives governments the excuse to intervene in industrial disputes ostensibly in order to solve them but effectively on the side of the employers. The intervention will be justified in terms of the national interest, or protecting the innocent public, but its effect will be to the detriment of labour. If no problem is seen as existing, it will be difficult to justify the intervention to the public. It must "create" a perceived problem in order to justify steps taken to solve it. The same process works in areas other than industrial relations. Foreign aid is one such other area where this process occurs. Strikes are particularly susceptible to this approach because the concept of an "innocent party" can often be introduced. They also have an element of conflict, sometimes violent, which polarises reactions. Existing social and class attitudes can also be exploited, plus an element of "threat" to the society can be introduced.

\section{A CONSENSUS WITH RESPECT TO THE RIGHT OF UNIONS TO BACK UP THEIR DEMANDS}

There is no such thing as a legal right to strike in New Zealand. There are many legal restrictions on union activity in New Zealand. Some of these are: The Industrial Relations Act (1973) and Amendments. S. 123 gives a wide definition of a "strike". S. 124 prevents a strike concerning a matter that is within the disputes procedure or the questioning of the decision reached. S. 125 defines "essential industries" which must give 14 days notice of intention to strike. S. 126 gives discretionary powers to order a secret ballot on a return to work during a strike. S. 128 provides for the suspension of non-striking 7 . Fox A (1973) Industrial Relations: A Social Critique of Pluralist Ideology. In J. Child (Ed) Man and Organization London, 
workers where work is not available during a strike. S. 130 provides for Ministerial deregistration of a union or cancellation of an award or agreement where in any "discontinuance of employment the Minister is satisfied that it has caused or is likely to cause serious loss or inconvenience". S. 149 prohibits any action taken "with the intention to defeat any of the provisions of any award or collective agreement" while the award is current.

The Commerce Amendment Act (1976) and Amendments. S. 119B prohibits any strike concerning a matter which is "not an industrial matter", or which the parties don't have the power to solve themselves, or which is "intended to coerce the New Zealand Government" either directly or indirectly by inflicting inconvenience upon the community. S. 119C provides for a return to full work where "the economy of New Zealand" or "the economy of a particular industry" is substantially or seriously affected by a strike. In addition any person who proves he is directly affected by a strike may apply for an order from the Arbitration Court restraining the strike.

The Public Safety Conservation Act (1932) provides that if at any time it appears to the Governor-General that any action has been taken or is immediately threatened in which "the public safety or public order is, or is likely to be imperilled", then he may by Order in Council make "all such regulations" as it "thinks necessary" to deal with the situation. Civil Injunctions in the private law of Contract and Torts are also available.

In Britain there has been a tradition of voluntarism in industrial relations with what Flanders calls "minor legal restrictions on the right to strike" ". ${ }^{8}$ There has been the use of injunctions, and recently a movement towards greater legal restrictions.

The International Labour Organisation has no right to strike amongst its Conventions and Recommendations. It concentrates mainly on the freedom of association concept. This is principally Convention 87 which provides that "workers and employers, without distinction whatsoever, shall have the right to establish and join organisations of their own choosing without previous authorisation'.9 It also provides for guarantees that organisations thus established shall "carry on their activities without interference from the public authorities'.

Significantly, New Zealand has not ratified Convention 87

\section{IS A CONSENSUS POSSIBLE?}

The unitary viewpoint regards a consensus with respect to the right of unions to back up their demands as unnecessary. Since all are in the same system together, and all have the same broad goals, then the concept of differing views is unthinkable. The unitarist concedes that strikes may occur, but these are the work of disrupters and deviants. The "reasonable" unionist will have settled earlier. Workers who take part in strikes are seen more as people who have been led astray, or dictated to by union leaders, or as lost sheep who have temporarily wandered from the fold. Those who return are handsomely rewarded, but those who stay out are outcast forever. The concept of a consensus with these people is unthinkable. "We will have no dealings with stirrers and malcontents and industrial wreckers." Those who oppose are not a 8 Flanders, A. (1970) Management and Unions London, Faber and Faber. p. 97.

9 International Labour Office (1978) International Labour Standards Geneva, I.L. 0. p. 29 
"loyal" opposition but are seen as outside the system. Opposition is seen as opposition to the system itself, and thus any consensus is impossible.

For the pluralist, consensus is everything. It is the heart of the whole system and the search for a consensus is in fact the be-all and end-all of the whole exercise. It is what "industrial relations" is all about. Elaborate structures are erected, carefully balanced, as a means of finding the consensus, and the process of developing a consensus is the constant goal. The existence and working of the system is the constant reaffirmation of consensus. The end result of the consensus will vary and fluctuate. But at any one time, the consensus about the right of unions to back up their demands is contained in the state of the system of the particular time. Examine the system - the laws, the norms, the decisions, the attitudes, the informal rules - and there you have the consensus. The method which is adopted is the balancing of rights. The "right" to strike against the "right" to uninterrupted production. The "right" to picket against the "right" to free passage along a highway, the "right" to boycott against the "right" to free trade, the "right" to secure employment against the "right" to hire and fire.

Like the unitary viewpoint, the radical viewpoint rejects the concept of consensus as unhelpful. The major reasons are : First, the parties are so unevenly matched with governments backing employers, that the concept of consensus in the sense of an agreement between evenly matched parties is seen as ridiculous. Secondly, even if a consensus was reached, at any time, about the right to back up demands, as soon as any effective means were found within the consensus, the consensus would be changed.

Miliband has clearly stated this view

Governments are deeply involved, on a permanent and institutionalised basis, in that 'routinisation of conflict', which is an essential part of the politics of advanced capitalism. They enter that conflict in the guise of a neutral and independent party, concerned to achieve not the outright defeat of one side or the other but a 'reasonable' settlement between them. But the state's intervention in negotiations occurs in the shadow of its known and declared propensity to invoke its powers of coercion, against one of the parties in the dispute rather than the other, if 'conciliation' procedures fail. These procedures form, in fact, an additional element of restraint upon organised labour, and also serve the useful purpose of further dividing the trade union ranks. The state does interpose itself between the 'two sides of industry' - not, however, as a neutral but as a partisan.

Nor is this nowadays only true when industrial disputes actually occur. One of the most notable features in the recent evolution of advanced capitalism is the degree to which governments have sought to place new and further inhibitions upon organised labour in order to prevent it from exercising what pressures it can on employers (and on the state as a major employer) in the matter of wage claims. ${ }^{10}$

The actions of the New Zealand Government in the 1970s gives an ample example of the actions Miliband talks of. The legal framework quoted earlier also gives ample examples of the process of changing consensus. The laws quoted have been amended many times since they were first introduced, and now con10 Miliband, R. (1973) The Stare in Capiralist Society London, Quartet Books. p. 70.

70 
tain wide discretionary powers which can be applied according to circumstances. Even those laws which have been repealed stand ready to be reintroduced should they be "required". The concept of a "consensus" within such a wide ranging and discretionarily applied legal framework is nonsense. No consensus is possible in New Zealand while such a legal framework exists.

\section{THE EFFECTS OF TECHNOLOGICAL CHANGES ON WORK PATTERNS IN THE AUSTRALIAN ECONOMY}

\section{GEORGE WITTINGSLOW*}

In the last year a growth industry has arisen - seminars and conference papers regarding technological change; mention the new fear word 'microprocessors' and one is guaranteed a large audience.

I he sudden burst of activity has not clarified many issues. In the main, we have witnessed the presentation of set piece speeches where ideology and values have been presented without factual information or without a meaningful frame of reference. When facts are given, they are not presented in a manner which allows integration with other information.

Even if such a frame of reference did exist, there is still the problem of accuracy regarding the forecast. The protagonists know that time must pass before any checking can be made on their claims, and often the actions based on the claims are irreversible by the time such checks can be made.

In 1950 the Rand Corporation predicted that the effects of the computer revolution would lead to just 2 per cent of the American workforce (4 - 5 million) working by 1980 (Tyler 1979). The latest figures show a workforce of 95 million with more than 60 per cent of the population actively employed the percentage in 1950 was 56 per cent. The demand for workers has risen through more holidays, longer vacations and a service economy not visualized thiry years ago.

The Rand predictors did note that the United States had the largest female workforce in the Western World, but expected this percentage to fall drastically. Today, Holland is the only OECD country with a female workforce of less than 30 per cent of its female population. (Benglson 1979)

In my allotted space I cannot hope to meet my complaints by presenting a detailed frame of reference and accurate predictions, but I shall try to cover as much as possible.

\section{MAJOR UNSTATED ASSUMPTIONS}

\section{IDEOLOGY OF CHANGE}

As a researcher in the field of organizational change it is quite eerie to read the important writings of two generations or more ago. Between 1880 and Dr George Wittingslow is Principal Lecturer in Psychology, Royal Melbourne Institute of Technology. This paper was originally
presented at the ANZAAS Jubilee Congress. Adelaide. Mav 1980 